\title{
HUMANIZAÇÃO DO PROCESSO CIVIL E EFETIVAÇÃO DA JUSTIÇA PELA DISTRIBUIÇÃO DINÂMICA DO ÔNUS DA PROVA
}

\author{
HUMANIZATION OF THE CIVIL PROCESS AND ENFORCEMENT OF JUSTICE THROUGH \\ THE DYNAMIC DISTRIBUTION OF THE BURDEN OF PROOF
}

\section{Adelson Luiz Correia}

Mestre em Direito pela Universidade Federal de Mato Grosso do Sul (UFMS); especialista em Direito Notarial e Registral e Direito de Família e Sucessões pela Uniderp; Graduado em Direito pelo Centro Universitário FAG. Tabelião de Notas e Registrador Civil das Pessoas Naturais. E-mail: luiz_adelson@hotmail.com

\section{Lídia Maria Ribas}

Doutora e Mestre em Direito do Estado pela PUC/SP. Pesquisadora e professora permanente do Mestrado em Direitos Humanos da UFMS. Coordenadora do Grupo de Pesquisas Direito, Políticas Públicas e Desenvolvimento Sustentável e pesquisadora no Grupo de Pesquisas - Tutela Jurídica das Empresas em face do Direito Ambiental Constitucional, ambos do CNPq. Membro do CEDIS/UNL.

E-mail: limaribas@uol.com.br

Recebido em: 25/05/2019

Aprovado em: 22/05/2020

RESUMO: A efetivação da justiça está intimamente ligada à forma de distribuição do ônus da prova no processo. Em regra, faz-se a distribuição conforme as alegações das partes, as quais nem sempre detêm condições de se desincumbir desse ônus, findando-se o processo com uma decisão injusta. Objetiva-se, portanto, conhecer as peculiaridades da prova e implicações na distribuição do ônus probandi para a concretização da justiça no processo civil brasileiro, debruçando-se sobre a Teoria da Distribuição Dinâmica do Ônus da Prova, adotada pelo Novo Código de Processo Civil (CPC de 2015). Parte-se de uma pesquisa descritiva e bibliográfica, tendo como fontes a lei, a doutrina e a jurisprudência para compreender e analisar o instituto da prova como um direito constitucional; conferir a compatibilidade da teoria da distribuição dinâmica do ônus da prova com os princípios que regem o processo e verificar de que maneira a distribuição dinâmica do ônus da prova contribui para a humanização do processo e para o acesso efetivo à justiça. Para tanto, abordam-se peculiaridades da prova, tais como conceito, objeto, finalidade e destinatário, bem como os fundamentos constitucionais do direito à prova; adiante, verificam-se a origem e conceito da teoria dinâmica e a sua compatibilidade com os princípios norteadores do processo civil brasileiro.

Palavras-chave: Acesso à Justiça. Direito Fundamental. Princípio da Cooperação.

ABSTRACT: The effectiveness of justice is closely linked to the way in which the burden of proof is distributed in the process. As a rule, distribution is made according to the claims of the parties, who are not always in a position to obtain the necessary information to bear this burden, ending 
the process with an unfair decision. The objective is, therefore, to know the peculiarities of the evidence and implications for the distribution of the burden of proof for the achievement of justice in the Brazilian civil process, focusing on the Dynamic Distribution Theory of the Burden of Proof, adopted by the New Code of Civil Procedure (CPC of 2015). It is based on a descriptive research and the law, the doctrine and the jurisprudence to understand and to analyze the institute of evidence as a constitutional right; confer the compatibility of the theory of distribution the burden of proof with the principles that govern the process and verify in what way the Dynamic distribution of the burden of proof contributes to the humanization of the process and to effective access to justice. To this end, the peculiarities of evidence are addressed, such as concept, object, purpose and as well as the constitutional grounds of the right to evidence; below, we verify the origin and the concept of dynamic theory and its compatibility with the guiding principles of civil procedure Brazilian.

Keywords: Burden of Proof. Access to justice. Fundamental rights. Judicial cooperation.

SUMÁRIO: Considerações iniciais; 1 Prova: Conceito, objeto, finalidade e destinatário; 2 O direito à prova como um direito fundamental; 3 Teoria da carga dinâmica: Origem, conceito e compatibilidade com os princípios norteadores do processo civil; 4 Contribuição da teoria da carga dinâmica para a humanização do processo e efetivação do acesso à justiça; Conclusões; Referências.

\section{CONSIDERAÇÕES INICIAIS}

Entre os institutos processuais, o ônus da prova assume especial relevância na efetivação da justiça na medida em que a ausência ou insuficiência de provas influi diretamente no convencimento de quem julga a causa, podendo até resultar em uma decisão, ao final do processo, totalmente contrária à pretendida pela parte, ensejando uma verdadeira injustiça.

Em contraposto à distribuição estática, a distribuição dinâmica mostra-se mais afeita à humanização do processo ao requerer das partes processuais uma postura cooperativa e solidária. Permite à autoridade judicial distribuir o ônus de acordo com a capacidade das partes que litigam, dando maior efetividade ao processo, em observância aos princípios constitucionais norteadores do direito processual civil.

Em regra, a produção das provas é feita pelas partes de acordo com o seu ônus de provar. Assim, é importante compreender o direito à prova como um direito fundamental; conferir a compatibilidade entre a Teoria da Distribuição Dinâmica do Ônus da Prova adotada pelo CPC de 2015 e os princípios constitucionais e, por fim, verificar de que maneira a dinamização do ônus da prova funciona como um instrumento de humanização do processo e de efetivação da justiça.

Seguindo a classificação de pesquisa proposta por Vergara (1998), esta pesquisa será descritiva e explicativa quanto aos fins; bibliográfica e documental quanto aos meios de investigação, tendo como fontes a lei, a doutrina e a jurisprudência.

Inicialmente, descrevem-se aspectos relacionados à prova, tais como conceito, objeto, finalidade e destinatário; em seguida, passa-se a compreender e analisar qualitativamente o direito à prova como um direito fundamental e sua base constitucional. Adiante, procede-se à investigação da origem e conceito da teoria da distribuição dinâmica do ônus da prova e sua compatibilidade com os princípios constitucionais. Por fim, analisa-se de que maneira esta forma de distribuição funciona como instrumento de humanização do processo e de efetivação da justiça. 


\section{PROVA: CONCEITO, OBJETO, FINALIDADE E DESTINATÁRIO}

O vocábulo prova pode ter mais de um significado, a depender do contexto em que é empregado, visto que "sua aplicação transcende o campo jurídico" (MACÊDO; PEIXOTO, 2014, p 63). Para fins deste trabalho, consideram-se os aspectos do vocábulo que são debatidos na doutrina brasileira, no que se refere à prova como instituto processual.

Nessa linha, na conceituação de Wambier e Talamini (2013, p. 497), “[...] prova é o modo pelo qual o magistrado forma convencimento sobre as alegações de fatos que embasam a pretensão das partes". Já para Didier (2013, p. 44, grifo do autor), a expressão tem dois sentidos: o sentido comum, no qual a prova seria a demonstração fática e o sentido jurídico:

[...] no sentido jurídico, são basicamente três as acepções com que o vocábulo é utilizado: a) às vezes, é utilizado para designar o ato de provar, é dizer, a atividade probatória; é nesse sentido que se diz que àquele que alega um fato cabe fazer prova dele, isto é, cabe fornecer os meios que demonstrem a sua alegação: b) noutras vezes, é utilizado para designar o meio de prova, propriamente dito, ou seja, as técnicas desenvolvidas para se extrair a prova de onde ela jorra; nesse sentido, fala-se em prova testemunhal, prova pericial, prova documental etc.; c) por fim, pode ser utilizado para designar o resultado dos atos ou dos meios de prova que foram produzidos no intuito de buscar o convencimento judicial e é nesse sentido que se diz, por exemplo, que o autor fez prova dos fatos alegados na causa de pedir.

Sobre o tema, em suas lições, Dinamarco (2004, p. 43) afirma que "[...] na dinâmica do processo e dos procedimentos, prova é conjunto de atividades de verificação e demonstração, mediante as quais se procura chegar à verdade quanto aos fatos relevantes para o julgamento".

No tocante ao objeto da prova, há divergência na doutrina, "[...] entendendo parcela da doutrina que são os fatos, enquanto outra parcela entende que são as alegações de fato" (NEVES, 2011, p. 411). Nesse ponto, há quem defenda que deve ser provado aquilo que se asseverou sobre o fato, mas não o fato em si, visto que não se pode afirmar se o fato é verdadeiro ou falso, mas sim se existiu ou não; já as afirmações sobre os fatos, essas sim, podem ser verdadeiras ou não (MARINONI, ARENHART, 2013, p. 262).

À margem da discussão se a prova tem por objeto os fatos ou as alegações sobre os fatos, Wambier e Talamini (2013) afirmam que os fatos é que devem ser provados, e não o direito. Citam os autores a máxima jura novit curia (o tribunal conhece o direito), de sorte que o direito é conhecido por quem julgará o caso, ao passo que os fatos devem restar provados, formando a convicção do julgador ao proferir sua decisão. O brocardo mihi factum, dabotibi jus (dá-me o fato que lhe dou o direito) resume o enredo (WAMBIER; TALAMINI, 2013, p. 501).

Deveras, o alcance da prestação jurisdicional pleiteada pelas partes depende das provas produzidas no curso do processo. Em regra, a situação fática precisa ser comprovada nos autos, pois, "[...] o direito, ordinariamente não se prova" (THEODORO JR, 2012. p. 439), visto que incumbe ao magistrado conhecê-lo, cabendo às partes a demonstração dos fatos pertinentes e relevantes em relação à causa.

Com efeito, cabe à parte narrar os fatos ao juízo, competindo a esse dizer o direito aplicado ao caso concreto. Uma exceção a essa regra está prevista no artigo 376 do CPC/2015, pelo que cabe à parte a prova da vigência do direito municipal, estadual, estrangeiro ou consuetudinário que invocar.

No que concerne à finalidade e ao destinatário da prova, Greco (2007, p. 196) afirma que “[...] a finalidade da prova é o convencimento do juiz, que é seu destinatário. No processo a prova não tem um fim em si mesmo ou um fim moral ou filosófico; sua finalidade é prática, ou seja, a de convencer o juiz.". 
Didier (2013) considera que o pensamento acima transcrito não é incorreto, mas precisa de complemento, e aponta a existência de três teorias acerca da finalidade da prova. A primeira aduz ter a prova a finalidade de estabelecer a verdade; a segunda afirma que a finalidade da prova é fixar os fatos postos no processo; a terceira, por sua vez, a que entende ser a mais correta, preconiza que a finalidade da prova é convencer o juiz. Didier (2013), contudo, defende que a prova não tem a finalidade de convencer apenas o juízo, mas também convencer as próprias partes.

Noutro vértice, destoando da tese sustentada por Didier, Wambier e Talamini (2013, p. 500) afirmam que "[...] o destinatário da prova é, sempre, o juiz. A prova não se destina ao autor nem à parte adversa, e uma vez produzida passa a integrar o processo, pouco importando quem teve a iniciativa de requerer sua produção".

Acerca desse tema, Nery Jr e Nery (2016) sustentam que o destinatário da prova é o processo:

O juiz deve julgar segundo o alegado em processo, vale dizer, o instrumento que reúne elementos objetivos para que o juiz possa julgar a causa. Portanto, a parte faz a prova para que seja adquirida pelo processo. Feita a prova, compete à parte convencer o juiz da existência do fato e do conteúdo da prova. Ainda que o magistrado esteja convencido da existência de um fato, não pode dispensar a prova se o fato for controvertido, não existir nos autos prova do referido fato e, ainda, a parte insistir na prova. Caso indefira a prova, nessas circunstâncias, haverá cerceamento de defesa. (NERY JR; NERY, 2016, p. 1.070).

Em que pesem algumas divergências sobre alguns aspectos relacionados à prova, não resta dúvida de que "[...] a prova tem por objetivo formar a convicção do juiz" (DONIZETTI, 2013, p. 555), pelo que, no primeiro plano, o seu principal destinatário é quem julga a causa, o que não afasta a possibilidade de as provas também convencerem as partes litigantes.

\section{O DIREITO À PROVA COMO UM DIREITO FUNDAMENTAL}

Hodiernamente, não se admite interpretações das normas infraconstitucionais que não sejam pautadas na Constituição Federal. Sem sombra de dúvidas, a Lei Maior é o centro motriz do ordenamento jurídico brasileiro, cujos princípios explícitos e implícitos iluminam o texto constitucional e a legislação infraconstitucional, norteando a atuação de quem interpreta e opera o direito.

A superposição da Constituição Federal decorre de um escalonamento de normas. As normas jurídicas não se situam todas em um mesmo plano, mas congregam-se em níveis diferentes, formando uma espécie de pirâmide, unidas pela dependência que estabelecem entre si, na medida em que a norma inferior busca seu fundamento de validade na norma imediatamente superior, e, assim, sucessivamente, até que se chegue ao topo (KELSEN, 1979).

Nesse sentido, Kelsen (1979, p. 247) leciona que:

A ordem jurídica não é um sistema de normas jurídicas ordenadas no mesmo plano, situadas umas ao lado das outras, mas é uma construção escalonada de diferentes camadas ou níveis de normas jurídicas. A sua unidade é produto da conexão de dependência que resulta do fato de a validade de uma norma, que foi produzida de acordo com outra norma, se apoiar sobra essa outra norma; e assim por diante, até abicar finalmente na norma fundamental - pressuposta. A norma 
fundamental - hipotética, nestes termos - é, portanto, o fundamento de validade último que constitui a unidade desta interconexão criadora. ${ }^{1}$

Em contraposto à concepção sociológica de Constituição descrita por Lassale (2001), na qual Constituição real é a soma dos fatores reais de poder e a Constituição escrita é mera folha de papel, Hesse (1991), por sua vez, afirma que a Constituição escrita (jurídica) possui força normativa, impondo tarefas, embora, por si só, não possa fazer nada. Para Hesse (1991, p. 19), “[...] a Constituição transforma-se em força ativa se essas tarefas forem efetivamente realizadas, se existir a disposição de orientar a conduta segundo a ordem nela estabelecida".

Verifica-se que na concepção de Hesse (1991, p. 11), a força normativa da Constituição possui um elemento volitivo humano:

[...] a Constituição converter-se-á em força ativa se fizerem-se (sic) presentes na consciência geral - particularmente, na consciência dos principais responsáveis pela ordem constitucional -, não só a vontade de poder (willw zur Macht), mas também a vontade de Constituição (Wille zur Verfassung). Essa vontade de Constituição origina-se de três vertentes diversas. Baseia-se na compreensão da necessidade e do valor de uma ordem normativa inquebrável, que projeta o Estado contra o arbítrio desmedido e disforme. Reside, igualmente na compreensão de que essa ordem constituída é mais do que uma ordem legitimada pelos fatos (e que, por isso, necessita estar em constante processo de legitimação). Assenta-se também na consciência de que, ao contrário do que se dá com uma lei do pensamento, essa ordem não logra ser eficaz sem o concurso da vontade humana.

Ao simplesmente conformar a Constituição à realidade social, Hesse (1991, p. 11) afirma que "[...] o Direito Constitucional não estaria a serviço de uma ordem estatal justa, cumprindo-lhe tão-somente a miserável função - indigna de qualquer ciência - de justificar as relações de poder dominantes".

À margem da discussão sobre o melhor sentido de Constituição, fato é que a Constituição escrita goza de supremacia sobre as demais normas do ordenamento jurídico brasileiro, impondose uma leitura dos institutos jurídicos à luz das normas constitucionais.

Nessa esteira, Barroso (2010, p. 86/87, grifos do autor) leciona que:

Sedimentado o caráter normativo das normas constitucionais, o Direito contemporâneo é caracterizado pela passagem da Constituição para o centro do sistema jurídico, onde desfruta não apenas da supremacia formal que sempre teve, mas também de uma supremacia material, axiológica. Compreendida como uma ordem objetiva de valores e como um sistema aberto de princípios e regras, a Constituição transforma-se no filtro através do qual se deve ler todo o direito infraconstitucional. Esse fenômeno tem sido designado como Constitucionalização do Direito, uma verdadeira mudança de paradigma que deu novo sentido e alcance a ramos tradicionais e autônomos do Direito, como o civil, o administrativo, o penal e o processual.

\footnotetext{
${ }^{1}$ Hans Kelsen é um dos grandes nomes da ciência jurídica. Suas teorizações não passaram incólumes a críticas e revisões, inclusive por ele mesmo, especialmente quanto à norma fundamental (Grundnorm). O tema é complexo e controvertido, palco de muitos debates ainda hoje. Nesse sentido, Sgarbossa (2010, p. 133-134) consigna que "Assim, parece plausível afirmar que a tentativa de criação de uma teoria do direito absolutamente "pura", livre de elementos éticos e políticos, e da autonomização do conhecimento jurídico, que não prescinde do construto da Grundnorm acabou por levar o normativismo a dilemas teóricos possivelmente insuperáveis." Ante a complexidade do tema, o aprofundamento nessa questão requer um trabalho próprio, pelo que foge à proposta desta pesquisa.
} 
Na toada de constitucionalização do direito, busca-se sempre uma compatibilização dos institutos legais aos preceitos constitucionalizados, mormente, aos princípios, sejam eles implícitos ou explícitos no texto constitucional.

O direito processual civil, com todos os seus institutos, bem como as demais áreas do direito, não está livre desta conformação com a Constituição, pelo que deve se espelhar no texto constitucional, e não o contrário.

Nesse contexto, considerando as disposições constitucionais, verifica-se que a prova tema tão relevante para o direito processual -, não é apenas um instrumento pelo qual se demonstra de forma cabal a ocorrência de um fato gerador de direito, ou até mesmo de fato impeditivo, modificativo ou extintivo de um direito anteriormente constituído. Em verdade, face à leitura constitucional do ordenamento jurídico, a produção da prova é um direito fundamental das partes.

A percepção da prova como um direito constitucional está intimamente ligada à concepção de direitos fundamentais previstos na Constituição Federal. Significa dizer que o direito à prova como direito fundamental decorre do princípio do devido processo legal, do princípio do contraditório e do acesso à justiça. Isso porque a compreensão contemporânea de processo legal alcança não somente os direitos de liberdade e os direitos patrimoniais, tal como estampado no art. $5^{\circ}$, inciso LIV, da Constituição Federal de 1988; seu alcance vai muito além, imiscuindo-se em vários outros direitos consagrados na Lei Maior.

Nesse sentido, Didier (2013, p.18) afirma que "[...] o direito à prova é conteúdo fundamental ao contraditório. A dimensão substancial do princípio do contraditório o garante. Nesse sentido, o direito à prova é também um direito fundamental”.

Aliás, vale ressaltar que muitos outros princípios constitucionais têm por base o princípio do devido processo legal, tais como:

Igualdade (art. $5^{\circ}$, caput, e I); inafastabilidade da jurisdição (art. $5^{\circ}, \mathrm{XXXV)}$; duplo grau de jurisdição (implícito); razoabilidade (implícito); juiz e promotor natural (art. $5^{\circ}$, XXXVII e LIII); contraditório e ampla defesa (art. $\left.5^{\circ}, \mathrm{LV}\right)$; proibição da prova ilícita (art. 5, LVI); motivação das decisões (art. 93, IX e X); publicidade (art. 5, LX, e 93, IX); razoável duração do processo (art. LXXVII); e presunção de inocência (art. 5\%, LVII). (BULOS, 2011, p. 355).

Na visão de Neves (2011, p. 40), “[...] a garantia do devido processo legal e do contraditório, ambos garantidos de forma expressa na Constituição Federal, alçam o direito à prova no processo civil ao patamar constitucional”.

O direito à prova está, portanto, ligado às garantias de um processo justo, o qual, em obediência aos preceitos constitucionais, conduz a causa à efetivação da justiça. Sobre o tema, Dinamarco (2004) leciona que:

[...] na Constituição, o direito à prova é inerência do conjunto de garantias do justo processo, que ela oferece ao enunciar os princípios do contraditório e ampla defesa, culminando por assegurar a própria observância destes quando garante a todos o due processo of Law (art. 50, incs. LIV e LV - supra, nn. 94 e 97). Pelo direito constitucional, direito à prova é a liberdade de acesso às fontes e meios segundo o disposto em lei e sem restrições que maculem ou descaracterizem o justo processo (DINAMARCO, 2004, p. 49, grifos do autor).

Ademais da contribuição doutrinária, há entendimento consolidado do Supremo Tribunal Federal, no sentido de que o direito à prova decorre diretamente do princípio do devido processo legal:

O exame da cláusula referente ao 'due process of law' permite nela identificar alguns elementos essenciais à sua configuração como expressiva garantia de 
ordem constitucional, destacando-se, dentre eles, por sua inquestionável importância, as seguintes prerrogativas: [...] (a) direito ao conhecimento prévio do teor da acusação; (c) direito a um julgamento público e célere, sem dilações indevidas; (d) direito ao contraditório e à plenitude de defesa (direito à autodefesa e à defesa técnica); (e) direito de não ser processado e julgado com base em leis 'ex post facto'; (f) direito à igualdade entre as partes; (g) direito de não ser processado com fundamento em provas revestidas de ilicitude; (h) direito ao benefício da gratuidade; (i) direito à observância do princípio do juiz natural; (j) direito ao silêncio (privilégio contra a auto-incriminação); (l) direito à prova; $\mathrm{e}$ (m) direito de presença e de 'participação ativa' nos atos de interrogatório judicial dos demais litisconsortes penais passivos, quando existentes (BRASIL, 2009, grifo nosso).

Portanto, ante a militância doutrinária, corroborada com o posicionamento assente do Supremo Tribunal Federal, é tranquilo afirmar que não resta dúvida de que o direito à prova foi erigido ao patamar constitucional, sedimentado como um verdadeiro direito fundamental das partes.

Inegavelmente, estando a produção de prova sob a égide de um direto fundamental, a forma como se dá a distribuição do onus probandi é de grande relevância para o deslinde do feito e, consequentemente, para a efetivação da justiça.

A regra de distribuição rígida (estática) adotada pelo anterior Código de Processo Civil (CPC/1973), sem previsão de exceções, acabava por violar direitos fundamentais, pois era incapaz de abranger todas as vicissitudes das relações sociais submetidas à apreciação do Poder Judiciário, transformando-se em empecilho à concretização de princípios fundamentais, tais como o do acesso à justiça, do direito à igualdade e do devido processo legal.

A dinamização do ônus da prova, ao flexibilizar a regra de distribuição estática do ônus probandi, possibilita uma análise do caso sub judice de acordo com suas peculiaridades e circunstâncias fáticas, de forma que as partes podem tirar maior proveito do processo (COUTO, 2011).

Eis que o CPC/2015 deu mais um passo em direção à efetivação da justiça por meio do processo ao permitir a distribuição dinâmica do ônus da prova.

\section{TEORIA DA CARGA DINÂMICA: ORIGEM, CONCEITO E COMPATIBILIDADE COM OS PRINCÍPIOS NORTEADORES DO PROCESSO CIVIL}

A Teoria da Distribuição Dinâmica do Ônus da Prova, de origem incerta, mas já adotada a seu modo por Jeremy Bentham, em 1823, foi aperfeiçoada pelo jurista argentino Jorge W. Peyrano (MACÊDO; PEIXOTO, 2014, p. 151).

Consagrada na Argentina, seus encantos romperam as fronteiras daquele país e têm influenciado vários outros ordenamentos jurídicos, a exemplo, o de Portugal, Brasil e Espanha, sendo, inclusive, a teoria, expressamente adotada pelo Código Processual Espanhol, para eles, Lei de Enjuciamiento Civil (BORGES, 2011).

A teoria em comento apregoa uma distribuição casuística do ônus da prova, com regras mais brandas, sem se olvidar de sopesar as circunstâncias fáticas que permeiam a lide, especialmente, a capacidade que cada parte ostenta em relação à produção das provas. A adoção dessa teoria pelo CPC/2015 é, em verdade, a superação da sistemática do CPC/1973, que prestigiava regras rígidas e invariáveis quanto ao ônus da prova, o que, muitas vezes, conduzia o processo a um final injusto.

Tal como defendia por Peyrano, a possibilidade da aplicação da distribuição dinâmica do ônus da prova não exclui, por si só, a incidência da distribuição estática; apenas excepciona a sua aplicação, de modo que quem julga o caso, ao analisar a demanda, poderá distribuir o ônus de 
acordo com a capacidade das partes em produzir as provas. Assim, tem-se que a teoria da distribuição dinâmica do ônus prova mitiga a teoria estática, mas não a substitui por completo. Pelo contrário, complementa-a, na medida em que possibilita o alcance da justiça, que não seria sempre possível com a aplicação exclusiva da regra estática (VICENTINI, 2013).

Importante frisar, também, a irrelevância do polo que a parte assume na lide, de modo que a regra dinâmica visa a garantir a produção da prova, e não a prestigiar uma das partes. Isso também se aplica à natureza do fato controvertido, não tendo relevância a natureza constitutiva ou desconstitutiva do fato aduzido (AZEVEDO, 2009).

O que se mostra de fato relevante nessa teoria é a possibilidade de a autoridade judicial, como gestora das provas, estabelecer o ônus de acordo com maior capacidade que as partes ostentam, independentemente de qual tenha levantado a alegação, visto que a prova é destinada a quem dará a sentença, e não às partes. Contudo, a distribuição dinâmica tem um pressuposto negativo de aplicação, que é a não imposição de prova diabólica à parte que passa a suportar o ônus redistribuído (DIDIER, 2013). Significa dizer que não poderá haver a distribuição dinâmica caso sua aplicação gere uma situação de prova impossível pela parte que passa a suportar o ônus da prova.

Theodoro Jr (2012) elenca requisitos a serem preenchidos para sua aplicação: a) a parte que passar a arcar com o ônus tem a missão de esclarecer os fatos, mas não de provar o fato constitutivo do direito do adversário; b) a possibilidade de realização da prova redirecionada, ou seja, não pode atribuir ônus de prova diabólica à parte; e c) a redistribuição deve ser em tempo que possibilite à parte se desincumbir do ônus que lhe foi atribuído; não pode gerar surpresa, sendo redistribuído na sentença.

A fixação do ônus de acordo com as peculiaridades do caso sub judice, serve para afastar a famigerada prova diabólica, cuja incidência gera grandes entraves à efetivação da justiça, além de aliviar a carga da parte que está em posição desfavorável em relação à produção da prova, aproximando, assim, os procedimentos do processo do escopo constitucional de acesso à justiça.

Nesse sentido, não se pode esquecer que a constitucionalização do direito exige uma leitura constitucional dos diplomas infraconstitucionais, de modo que "[...] toda a ordem jurídica deve ser lida e apreendida sob a lente da Constituição" (BARROSO, 2010, p. 364). Ademais da leitura constitucional do direito, a própria Constituição deixou de ser um documento essencialmente político, passando a ter força normativa, sendo seus preceitos carregados de imperatividade.

Neste diapasão, inegável a compatibilidade da distribuição dinâmica do ônus da prova com ordenamento jurídico brasileiro, tornando-se a teoria ainda mais sedutora, quando analisada sob o enfoque dos princípios constitucionais da dignidade da pessoa humana, do acesso à justiça, do devido processo legal e da isonomia. Não bastassem os princípios constitucionais, inolvidável o moderno princípio processual da cooperação, expressamente consagrado no artigo $6^{\circ}$ do $\mathrm{CPC} / 2015$.

Antes mesmo da previsão legal do princípio em comento, sua aplicação já repercutia na jurisprudência brasileira, como se percebe nas seguintes ementas:

PROCESSUAL CIVIL. AMPLIAÇÃO OBJETIVA DA DEMANDA. NECESSIDADE DECONSENTIMENTO DO RÉU. IMPOSSIBILIDADE DE CONSENTIMENTO TÁCITO. DUEPROCESS OF LAW. OBSERVÂNCIA DOS PRINCÍPIOS DO CONTRADITÓRIO E DA AMPLA DEFESA. 1. [...] Aliás, é o que se consagra no princípio da cooperação, que "orienta o magistrado a tomar uma decisão de agente-colaborador do processo, de participante ativo do contraditório e não mais de mero fiscal de regras" (Fredie Didier Jr. em Curso de Direito Processual Civil). [...] (STJ, Relator: Ministro MAURO CAMPBELL MARQUES, Data de Julgamento: 22/05/2012, T2 - SEGUNDA TURMA) (BRASIL, 2012, grifo nosso) 
EMBARGOS DE DECLARAÇÃO. AGRAVO DE INSTRUMENTO. PEDIDO DE DESISTÊNCIA DO RECURSO. DÚVIDA RAZOÁVEL EM RELAÇÃO AO INTENTO DO RECORRENTE. ESCLARECIMENTO. POSSIBILIDADE. PRINCÍPIO DA COOPERAÇÃO. VIOLAÇÃO AO ART. 535 DO CPC. INOCORRÊNCIA. ALTERAÇÃO, EM FASE DE CUMPRIMENTO DE SENTENÇA, DE CRITÉRIO DE CORREÇÃO MONETÁRIA. IMPOSSIBILIDADE. ERRO MATERIAL. INEXISTÊNCIA. 1. Diante das peculiaridades do caso concreto e em atenção ao dever de esclarecimento decorrente do moderno princípio processual da cooperação, incumbia ao julgador oportunizar ao agravante as explicações necessárias acerca das petições conflitantes atravessadas na espécie. [...] (STJ, Relator: Ministro PAULO DE TARSO SANSEVERINO, Data de Julgamento: 05/10/2010, T3 - TERCEIRA TURMA) (BRASIL, 2010, grifo nosso).

Com efeito, a dinamização do ônus da prova está em harmonia com a ideia de um processo civil cooperativo, cujo fundamento está na "[...] necessidade de velar-se por uma efetiva igualdade entre as partes no processo e por uma escorreita observação dos deveres de cooperação" (MITIDIEIRO, 2012, p. 73/74).

De fato, a aplicação da distribuição dinâmica do ônus da prova, no dever de cooperação, favorece a produção da prova, levando a autoridade judicial a prestar a tutela jurisdicional mais adequada, equalizando as forças, na medida em que distribui o ônus da prova de acordo com as possibilidades que as partes têm de se desincumbirem do ônus que lhe for imputado, cooperando, assim, para uma decisão judicial mais justa, concretizando um dos objetivos fundamentais da República Federativa do Brasil, qual seja, o da construção de uma sociedade justa (MACÊDO; PEIXOTO, 2014).

Conforme explanado, a teoria da distribuição dinâmica do ônus da prova encontra respaldo na Constituição Federal de 1988, sendo, portanto, imprescindível a releitura do direito processual civil atual sob a ótica constitucional.

Notadamente, a distribuição rígida, previamente fixada, do ônus da prova, como regra absoluta, não se compatibiliza com a dinamicidade das relações sociais e com a evolução tecnológica do mundo contemporâneo, que reclamam uma nova abordagem sobre os meios, o objeto, quem produz e a quem se destinam as provas.

Inegavelmente, a aplicação da distribuição estática, de forma absoluta, ofende preceitos constitucionais na medida em que aumenta as desigualdades entre as partes, impossibilitando, ainda, a amplitude probatória, uma vez que não permite a distribuição do ônus da prova de acordo com as possibilidades das partes de produzirem as provas necessárias ao deslinde justo do feito (COUTO, 2011).

Atento aos reclames de uma abordagem constitucional do direito, embora ainda não houvesse previsão legal para a aplicação da distribuição dinâmica do ônus da prova, o Poder Judiciário, em uma interpretação sistemática do ordenamento jurídico, já aplicava a distribuição dinâmica do ônus da prova, visto que o instituto está em harmonia com Constituição Federal e dá maior efetividade aos direitos fundamentais.

Nesse sentido, há julgados dos Tribunais nos quais se tem aplicado a teoria no caso concreto, conforme colacionados:

PROCESSUAL CIVIL. PENHORA. DEPÓSITOS EM CONTAS CORRENTES. NATUREZASALARIAL. IMPENHORABILIDADE. ÔNUS DA PROVA QUE CABE AO TITULAR. 1. Sendo direito do exequente a penhora preferencialmente em dinheiro (art. 655, inciso I, do CPC), a impenhorabilidade dos depósitos em contas correntes, ao argumento de tratar-se de verba salarial, consubstancia fato impeditivo do direito do autor (art.333, inciso II, do CPC), recaindo sobre o réu o ônus de prová-lo. 2. Ademais, à luz da teoria da carga dinâmica da prova, não 
se concebe distribuir o ônus probatório de modo a retirar tal incumbência de quem poderia fazê-lo mais facilmente e atribuí-la a quem, por impossibilidade lógica e natural, não o conseguiria. 3. Recurso especial conhecido e parcialmente provido. (STJ, Relator: Ministro LUIS FELIPE SALOMÃO, Data de Julgamento: 20/10/2010, T4 - QUARTA TURMA) (BRASIL, 2010, grifo nosso).

A Teoria da distribuição dinâmica do ônus da prova também é prestigiada no Superior Tribunal de Justiça:

PROCESSUAL CIVIL. AGRAVO REGIMENTAL NO AGRAVO EM RECURSO ESPECIAL. EMPRÉSTIMO COMPULSÓRIO SOBRE ENERGIA ELÉTRICA. EXIBIÇÃO DEDOCUMENTOS PARA A VERIFICAÇÃO DOS VALORES RECOLHIDOS NAS CONTAS DE ENERGIA ELÉTRICA. RESPONSABILIDADE DA ELETROBRÁS. 1. Pode o juiz ordenar que a Eletrobrás exiba documento que se ache em seu poder, a fim de permitir-se que sejam efetuados corretamente os cálculos dos valores devidos em razão da correção monetária dos valores recolhidos a título de empréstimo compulsório. Essa providência é salutar e caminha rumo ao princípio da efetividade da prestação jurisdicional, já que nessas ações são questionados valores referentes a quase quinze anos - normalmente valores relativos aos recolhimentos efetuados

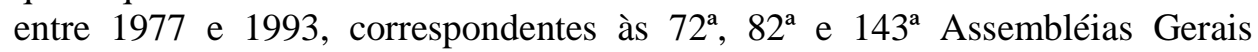
Extraordinárias da Eletrobrás, que homologaram respectivamente a $1^{\mathrm{a}}$, a $2^{\mathrm{a}}$ e a $3^{\mathrm{a}}$ conversões dos créditos em ações preferenciais - não sendo razoável exigir do contribuinte que guarde todas as suas contas mensais de energia elétrica a fim de calcular o devido. De fato, compete à Eletrobrás manter o exato controle dos valores pagos e a serem devolvidos a título de empréstimo compulsório sobre energia elétrica, até porque é a própria Eletrobrás que constitui os créditos escriturais em favor dos contribuintes, os atualiza, sobre eles paga juros e posteriormente os converte em ações. 2. Não há qualquer ilegalidade na determinação judicial para que a Eletrobrás, ora recorrente, apresente os documentos mencionados. Isso porque a teoria de distribuição dinâmica do encargo probatório propicia a flexibilização do sistema, e permite ao juiz que, diante da insuficiência da regra geral prevista no art. 333 do CPC, possa modificar o ônus da prova, atribuindo-o à parte que tenha melhor condições de produzi-la. Logo, não há que se falar em contrariedade aos arts. 283, 333, I, e 396 do CPC. 3. Agravo regimental não provido. (STJ, Relator: Ministro MAURO CAMPBELL MARQUES, Data de Julgamento: 23/10/2012, T2 SEGUNDA TURMA) (BRASIL, 2012, grifo nosso).

CIVIL E PROCESSO CIVIL. PEDIDO. INTERPRETAÇÃO. CRITÉRIOS. PROVA. ÔNUS. DISTRIBUIÇÃO. LITIGÂNCIA DE MÁ FÉ. COBRANÇA DE DÍVIDA JÁ PAGA. LIMITES DE INCIDÊNCIA. DISPOSTIVOS LEGAIS ANALISADOS: ARTS. 17, 18, 125, I, 282, 286, 333, I E II, 339, 355, 358, 359, 460 E 512 DO CPC; E 1.531 DO CC/16 (940 DO CC/02). 1. [...] 6. Nos termos do art. 333, II, do CPC, recai sobre o réu o ônus da prova da existência de fato impeditivo, modificativo ou extintivo do direito do autor. 7. Embora não tenha sido expressamente contemplada no CPC, uma interpretação sistemática da nossa legislação processual, inclusive em bases constitucionais, confere ampla legitimidade à aplicação da teoria da distribuição dinâmica do ônus da prova, segundo a qual esse ônus recai sobre quem tiver melhores condições de produzir a prova, conforme as circunstâncias fáticas de cada caso. [...] (STJ, Relator: Ministra NANCY ANDRIGHI, Data de Julgamento: 22/10/2013, T3 TERCEIRA TURMA). (grifo nosso) (BRASIL, 2013, grifo nosso). 
Conquanto a teoria já tivesse certa aplicação na prática, foi de bom alvitre a sua adoção de forma expressa pelo CPC/2015, uma vez que as decisões supracitadas não possuem caráter vinculante, tendo eficácia apenas entre as partes.

$\mathrm{Na}$ exposição de motivos do anteprojeto do CPC/2015, entre outros objetivos explícitos, encontra-se o de "criar condições para que o juiz possa proferir decisão de forma mais rente à realidade fática subjacente à causa" (BRASIL, 2010, p. 14). Há uma preocupação da nova legislação em consagrar uma "[...] forma de tornar o processo mais eficiente e efetivo, o que significa, indubitavelmente, aproximá-lo da Constituição Federal, em cujas entrelinhas se lê que o processo deve assegurar o cumprimente da lei material” (BRASIL, 2010, p. 14).

A previsão da distribuição dinâmica do ônus da prova tem substrato principiológico que não foi ignorado pelo $\mathrm{CPC} / 2015$, visto que "[...] a visão solidarista do ônus da prova, focada na atuação das partes, preocupa-se com a plena aplicação dos princípios da solidariedade e da cooperação ao processo, afastando-se da visão individualista” (AZÁRIO, 2006, p. 139).

Conforme estabelece o art. $6^{\circ} \mathrm{CPC} / 2015$, “Todos os sujeitos do processo devem cooperar entre si para que se obtenha, em tempo razoável, decisão de mérito justa e efetiva" (BRASIL, 2015). Já o art. $7^{\circ}$ garante a paridade de tratamento em relação ao exercício de direitos e faculdades processuais, dentre eles os meios de defesa e ônus.

Art. 373. O ônus da prova incumbe:

I - ao autor, quanto ao fato constitutivo do seu direito;

II - ao réu, quanto à existência de fato impeditivo, modificativo ou extintivo do direito do autor.

$\S 1^{\circ}$ - Nos casos previstos em lei ou diante de peculiaridades da causa relacionadas à impossibilidade ou à excessiva dificuldade de cumprir o encargo nos termos do caput ou à maior facilidade de obtenção da prova do fato contrário, poderá o juiz atribuir o ônus da prova de modo diverso, desde que o faça por decisão fundamentada, caso em que deverá dar à parte a oportunidade de se desincumbir do ônus que lhe foi atribuído.

$\S 2^{\circ}$ - A decisão prevista no $\S 1^{\circ}$ deste artigo não pode gerar situação em que a desincumbência do encargo pela parte seja impossível ou excessivamente difícil. (BRASIL, 2015).

Sustentam Macêdo e Peixoto (2014, p. 233) que a redação primária do projeto de lei, que previa dois artigos disciplinando a distribuição do ônus da prova, qual seja, estática e dinâmica, respectivamente, nos artigos 261 e 262 do Anteprojeto PLS 166/2010, traria dificuldade em se reconhecer a subsidiariedade da dinamização do ônus probandi, o que poderia levar ao "entendimento no sentido da existência de duas regras autônomas" de distribuição do ônus.

Contudo, a unificação dos dois artigos em apenas um artigo (373), tal como visto acima, evidencia que o CPC/2015 adota a teoria estática de distribuição do ônus da prova como a regra para o sistema processual, sendo, portanto, a distribuição dinâmica uma exceção justificável pelas peculiaridades do caso concreto.

Com efeito, a mens legislatoris resta ainda mais acentuada quando analisada à luz da Lei Complementar $n^{\circ}$ 95/1998, que dispõe sobre a elaboração, redação, alteração e consolidação das leis, tendo o inciso III do artigo 11 a seguinte redação:

Art. 11. As disposições normativas serão redigidas com clareza, precisão e ordem lógica, observadas, para esse propósito, as seguintes normas:

\section{III - para a obtenção de ordem lógica:}

a) reunir sob as categorias de agregação - subseção, seção, capítulo, título e livro - apenas as disposições relacionadas com o objeto da lei; 
b) restringir o conteúdo de cada artigo da lei a um único assunto ou princípio;

c) expressar por meio dos parágrafos os aspectos complementares à norma enunciada no caput do artigo e as exceções à regra por este estabelecida;

d) promover as discriminações e enumerações por meio dos incisos, alíneas e itens. (BRASIL, 1998, grifo nosso).

Embora harmoniosa com os princípios constitucionais do processo, a dinamização requer a sensibilidade de quem julga ao apreciar o caso concreto, distribuindo o ônus probandi de acordo com as condições que a parte sustentar. Em que pesem as louváveis benesses da teoria, há de ser ter cautela na sua aplicação, visto que a dinamização do ônus da prova deve ser exceção à regra estática de distribuição, sob pena de novamente se engessar o instituto, tal como ocorria no cenário do antigo Código Processual.

\section{CONTRIBUIÇÃO DA TEORIA DA CARGA DINÂMICA PARA A HUMANIZAÇÃO DO PROCESSO E EFETIVAÇÃO DO ACESSO À JUSTIÇA.}

Pela sistemática do CPC de 1973, o ônus da prova servia como uma válvula de escape para quem teria de julgar, uma vez que não podia declinar de sua missão de decidir a lide sobre pretexto de falta de provas (non liquet), pois caso não houvesse prova suficiente para firmar seu convencimento, proferiria sua decisão de acordo com o ônus de cada parte, de sorte que era improcedente o pedido da parte autora formulado com base apenas em alegações, que não restassem provadas, ou com provas insuficientes para o convencimento do juízo.

A regra estática do onus probandi já recebia severas críticas por parte da doutrina processualista. Apontava-se a perda da legitimidade do sistema processual por não acompanhar a evolução social, sendo considerado um modelo ultrapassado, principalmente em relação à regra rígida de distribuição do ônus da prova, que era fixada "antes mesmo dos fatos acontecerem no mundo real, como se a norma fosse possível a prever todas as hipóteses prováveis e plausíveis e enquadrá-las nessa mesma norma Jurídica" (COUTO, 2011, p. 14).

Neste contexto, Arenhart (2006) defendia uma modificação necessária no regime de distribuição do ônus da prova, consubstanciada nos preceitos constitucionais, visto que o CPC, sendo uma norma infraconstitucional, devia estar em consonância com o texto constitucional. A regra rígida de distribuição do ônus da prova inadvertidamente aplicada, eventualmente, impediria a tutela do direito material.

A distribuição estática demonstra “[...] pouca preocupação com a justiça do caso concreto, mas apenas com a mera solução do caso - 'justiça da lei', não se perquirindo quem é mais hábil a provar ou se a aplicação da regra, em certas situações, provoca injustiça" (MACÊDO; PEIXOTO, 2014, p. 153 e 154).

A teoria da distribuição dinâmica, por sua vez, coaduna-se com os princípios constitucionais informadores do processo civil e supera mais um dos muitos empecilhos do acesso à justiça. Vale ressaltar que o direito e princípio do acesso à justiça tem ganhado nova roupagem, não pode mais ser lido como o mero ajuizamento de ações perante o Poder Judiciário. Nos últimos anos, apregoa-se uma nova leitura do acesso à justiça, não mais como o tradicional e vetusto acesso aos tribunais ou direito de ação, mas como o acesso efetivo à ordem jurídica justa.

Nas lições de Watanabe (1988, p. 128), o acesso à justiça não se limita ao mero acesso aos órgãos jurisdicionais, "[...] não se trata apenas de possibilitar o acesso à Justiça enquanto instituição estatal e sim de viabilizar o acesso à ordem jurídica justa".

Para Grinover (2006, p. 303), o acesso à justiça "um dos mais caros aos olhos processualistas contemporâneos, não indica apenas o direito de aceder aos tribunais, mas também o de alcançar, por meio de um processo cercado das garantias do devido processo legal, a tutela efetiva dos direitos violados ou ameaçadas". 
No mesmo sentido, Dinamarco (2004), afirma que a mera propositura da ação judicial não equivale a acesso à justiça. Acesso à justiça é acessar a ordem jurídica justa, é obter justiça substancial, e justiça substancial é receber uma solução tempestiva, bem formulada e que melhore a vida em relação ao bem pretendido.

Não se pode ignorar que a reprodução fidedigna do fato é de dificuldade extrema, quiçá, impossível. O caminho a ser percorrido pela parte para provar seu direito pode ser muito tortuoso e pode até mesmo impedir que se alcance o bem de vida pretendido. Por outro lado, a parte antagonista pode estar muito mais apta a cooperar para o esclarecimento dos fatos e para formar a convicção de quem proferirá a decisão.

É preciso, portanto, que se estabeleça o equilíbrio entre as partes, especialmente na produção das provas. Assim, a dinamização do ônus possibilita uma equalização das forças e garante a observância do princípio constitucional da isonomia na sua perspectiva substancial.

Nesse contexto, a distribuição dinâmica do ônus da prova se encaixa perfeitamente na descrição de acesso à justiça empregado por Paroski (2008, p. 142):

A aplicação do princípio do acesso à justiça implica em um processo justo e imparcial, mas não só isso, devendo ser incluída a garantia de igualdade de oportunidade às partes litigantes, com participação efetiva e adequada na relação processual, o que se coaduna com o regime democrático e com o exercício da cidadania.

A dinamização do ônus da prova, portanto, guarda uma relação estreita com os princípios do acesso efetivo à justiça e da dignidade da pessoa, e torna, por sua vez, o processo mais humano, na medida em que não só permite, como também exige, uma postura positiva por parte de quem julgará a lide, na busca pela a verdade real, que sopesará as particularidades do caso e das partes, caminhando, assim, para uma solução mais adequada e justa.

Com efeito, essa dinamização possibilita evitar a despessoalização da pessoa humana, verificada na rotulação costumeira "autor e réu"; "demandante e demandado", e expressões afins. A teoria da distribuição dinâmica do ônus da prova suaviza a robotização do processo e categorização da pessoa humana, como bem sentencia Macedo (2016, p. 272, grifos da autora) que:

O sujeito de direito, no exercício de sua cidadania e dotado de dignidade humana, ao se colocar no processo como pretenso titular de um direito subjetivo, passa a ser, na condição de "parte", catalogado, rotulado, reconhecido como "autor", "réu", "assistente", "chamado ao processo", "denunciado à lide", "terceiro interessado", "recorrente", "recorrido", etc.

Pode-se afirmar, então, que a distribuição dinâmica afasta a frieza da decisão fundamentada unicamente na distribuição estática, bem como a indiferença de quem decide a lide, em relação às partes. Antes de meras partes contendoras, o juízo tem diante de si seres humanos, dotados de dignidade e valores, que precisam de uma resposta estatal para suas contendas.

A humanização do processo é um passo que requer a reconsideração dos paradigmas processuais e se coloca como um desafio a ser vencido, o qual Macedo (2016, p. 272) assim o descreve:

Este é o desafio: humanizar o processo e resgatar os valores éticos, sociais, culturais, de amor ao próximo, de solidariedade: pessoalizar os que integram o processo, superar a ideia de mera sujeição para retomar a ideia de agente - quem atua/age no processo é corresponsável pelo resultado final -, humanizar o conflito rompendo com a abstratização, substancializando-o, desvelando suas circunstâncias, suas peculiaridades. Olhar as pessoas como submersas em múltiplas situações fáticas e suas implicações, entre as quais o jurídico. 


\begin{abstract}
Substancializar o conflito no espaço do processo é, ao lado da constitucionalização do processo, a abordagem para a sua humanização. Compreender o autor não como autor, mas como uma pessoa de carne e osso, com suas contingências e limitações, atuando no cotidiano e no mundo fenomênico como titular de direitos, obrigações, deveres, prerrogativas, como ser que acumula e vivencia perdas e sofrimentos. Olhar o conflito pela sua concretude, pela complexidade fática e jurídica que ele possa representar, pontuar cada particularidade, a pluralidade ínsita aos movimentos humanos, sob a lente dos valores constitucionais.
\end{abstract}

Nesse diapasão, tendo o Estado avocado para si, primordialmente, o poder de dizer o direito, deve fazê-lo em sua maior medida de justiça, o que só é possível considerando as condições das partes, sob a sinalização das peculiaridades da natureza humana, especialmente, quanto às forças e fraquezas que demonstram em relação à produção das provas do bojo do processo.

A humanização do processo pela aplicação da teoria da distribuição dinâmica do ônus da prova não significa permitir a parcialidade de quem julga, mas, sim, dar aplicação e efetividade aos princípios da dignidade da pessoa humana, do acesso à justiça, do devido processo legal e da isonomia.

Dessa forma, a decisão que aplica, devidamente fundamentada, a dinamização do ônus da prova, corrobora para a humanização do processo e efetivação da justiça, com a entrega de uma prestação justa, com equilíbrio das forças e oportunidades às partes.

\title{
CONCLUSÕES
}

A produção de provas no processo não é mera faculdade das partes, mas um verdadeiro direito fundamental, pautado nos princípios do devido processo legal, da isonomia e do acesso à justiça.

Encarregada do convencimento da autoridade judicial, a prova assume especial relevância no deslinde do caso, de forma que a maneira como o ônus da prova é distribuído repercute diretamente na efetivação do acesso à justiça, visto que não é tido mais como mero acesso ao Judiciário, mas como a entrega da prestação jurisdicional justa, tempestiva e adequada ao caso concreto.

As distribuições estáticas e dinâmicas não se excluem mutuamente, mas completam-se. Enquanto aquela prevalece como a regra; essa lhe excepciona e abranda a frieza.

Embora a teoria da distribuição dinâmica já fosse defendida e até mesmo aplicada por órgãos do Poder Judiciário, sua adoção pelo CPC 2015 aponta para um novo rumo da efetivação da justiça. A positivação demonstra a preocupação por parte da doutrina, acolhida pela legislação, com a busca da entrega da prestação jurisdicional com justiça.

O tempo tem trazido novas percepções acerca da amplitude do conceito de justiça, e isso tem contribuído para afastar as friezas e indiferentes das regras do processo, tornando mais humano e condizente com a busca pela efetivação do acesso à justiça.

A dinamização do ônus da prova vai ao encontro da efetivação da justiça, ao proporcionar a possibilidade de o juízo equalizar a demanda, afastando a despessoalização dos envolvidos, devolvendo-lhes os atributos pessoais e próprios da pessoa humana, dos quais a regra estática os despia ao ingressar com a ação.

\section{REFERÊNCIAS}

ARENHART, Sérgio Cruz. Ônus da prova e sua modificação no processo civil brasileiro. Revista Jurídica, v. 343, p. 25-60, 2006. Disponível em: 
http://www.abdpc.org.br/abdpc/artigos/Sergio\%20Cruz\%20Arenhart\%20-

$\% 20$ onus \%20da\%20prova\%20e\%20sua\%20modifica\%C3\%83\%C2\%A7\%C3\%83\%C2\%A3o\%2 0no\%20dpc.pdf. Acesso em: 24 ago. 2017.

AZÁRIO, Márcia Pereira. Dinamicização da distribuição do ônus da prova no processo civil brasileiro 2006. Dissertação (Mestrado em Direito) - Faculdade de Direito da Universidade Federal do Rio Grande do Sul, 2006, Porto Alegre, 2006. Disponível em:

http://www.lume.ufrgs.br/bitstream/handle/10183/7478/000545981.pdf. Acesso em: 16 de mai. de 2018.

AZEVEDO, Antonio Danilo Moura de. A teoria dinâmica de distribuição do ônus da prova no direito processual civil brasileiro. Jus Navigandi, Teresina, ano 12, n. 1500, 10 ago. 2007. Disponível em: http://jus.com.br/artigos/10264. Acesso em: 02 mai. 2017.

BARROSO, Luís Roberto. Curso de Direito Constitucional Contemporâneo: os conceitos fundamentais e a construção do novo modelo. 2. ed. Saraiva, 2010.

BORGES, Felipe Eduardo Galeno. O ônus da prova no código de processo civil. 2012.

Trabalho de conclusão de curso (Bacharelado em Direito) - Faculdade de Direito da Universidade de Brasília, Brasília, 2012. (UnB) Disponível em:

http://bdm.bce.unb.br/bitstream/10483/2911/1/2011_FelipeEduardoGalenoBorges.pdf. Acesso em: 09 de mai. de 2017.

BRASIL. Lei Complementar $\mathbf{n}^{0}$ 95, de 26 de fevereiro de 1998. Dispõe sobre a elaboração, a redação, a alteração e a consolidação das leis [...]. Disponível em:

http://www.planalto.gov.br/ccivil_03/leis/lcp/lcp95.htm. Acesso em: Acesso em: 20 de fev. de 2019.

BRASIL. Lei no 5.869, de 11 de janeiro de 1973. Institui o Código de Processo Civil. Disponível em: http://www.planalto.gov.br/ccivil_03/leis/15869compilada.htm. Acesso em: 20 de fev. de 2019.

BRASIL. Lei ${ }^{\circ}$ 13.105, de 16 de março de 2015. Institui o Código de Processo Civil. Disponível em: http://www.planalto.gov.br/ccivil_03/_ato2015-2018/2015/lei/113105.htm. Acesso em: 20 de fev. de 2019.

BRASIL. Superior Tribunal de Justiça. Quarta Turma. Recurso Especial 619148 / MG. Recorrente: Banco Rural S/A. Recorrido: Indústrias Reunidas de Colchões LTDA - IRCOL e outros. Relator: Min. LUIS FELIPE SALOMÃO, Data de Julgamento: 20/10/2010. DJe 01/06/2010. Disponível em:

https://ww2.stj.jus.br/processo/revista/documento/mediado/?componente=ITA\&sequencial=9740 $18 \&$ num_registro=200302319623\&data $=20100601 \&$ formato=PDF. Acesso em: 20 de fev. de 2019.

BRASIL. Superior Tribunal de Justiça. Segunda Turma. Agravo Regimental no Agravo em Recurso Especial 216315 / RS. Agravante: Centrais Elétricas Brasileiras S/A ELETROBRÁS Agravado: Sulpino LTDA.

Relator: Min. MAURO CAMPBELL MARQUES, Data de Julgamento: 23/10/2012. DJe 06/11/2012. Disponível em:

https://ww2.stj.jus.br/processo/revista/documento/mediado/?componente=ITA\&sequencial=1189 
626\&num_registro=201201686355\&data=20121106\&formato=PDF. Acesso em: 20 de fev. 2019.

BRASIL. Superior Tribunal de Justiça. Terceira Turma. Recurso Especial 1286704/SP. Recorrente: Transbrasil S/A Linhas Aereas E Outros. Recorrido: Os Mesmos.

Relatora: Min. NANCY ANDRIGHI, Data de Julgamento: 22/10/2013. DJe 28/10/2013. Disponível em:

https://ww2.stj.jus.br/processo/revista/documento/mediado/?componente=ITA\&sequencial=1275 620\&num_registro=201102426968\&data=20131028\&formato=PDF. Acesso em: 20 de fev. de 2019.

BRASIL. Supremo Tribunal Federal, Segunda Turma. Habeas corpus n. 94.601-1/ CE. Relator: Min. Celso de Melo. Julgamento: 04/08/2009. DJe 171, de 11.09.09). Disponível em: http://www.stf.jus.br/arquivo/cms/noticianoticiastf/anexo/hc94601.pdf. Acesso em: 20 de fev. 2019.

BULOS, Uadi Lammêgo. Direito Constitucional ao alcance de todos. 3. ed. São Paulo: Saraiva, 2011.

COUTO, Camilo José D’Ávila. Dinamização do ônus da prova: teoria e prática. 2011. Tese (Doutorado em Direito Processual) - Faculdade de Direito, Universidade de São Paulo, São Paulo, 2011. Disponível em: http://www.teses.usp.br/teses/disponiveis/2/2137/tde-05072012140925/. Acesso em: 29 de abril de 2017.

DIDIER JR, Fredie; et al. Curso de Direito Processual Civil: Teoria da Prova, Direito Probatório, Ações Probatórias, Decisão, Precedente, Coisa Julgada e Antecipação da Tutela. 8. ed. Juspodivm, 2013.

DINAMARCO, Cândido Rangel. Instituições de Direito Processual Civil. 5. Ed, revista e atualizada de acordo com a emenda constitucional n.45 de 8.12.2004. São Paulo: Malheiros, 2004.

DONIZETE, Elpídio. Curso Didático de Processo Civil. 17 ed. São Paulo: Atlas, 2013.

GRECO FILHO, Vicente. Direito Processual Civil Brasileiro. Vol. 2: (atos processuais a recursos e processos nos tribunais. 18. ed. rev. e atal. - São Paulo: Saraiva, 2007.

GRINOVER, Ada Pellegrini; et al. In: Tutela Coletiva: 20 anos da Lei da Ação Civil Pública e do Fundo de Defesa de Direitos Difusos, 15 anos do Código de Defesa do Consumidor / Paulo Henrique dos Santos Lucon (coord). - São Paulo: Aplas, 2006.

HESSE, Konrad. A Força Normativa da Constituição. Tradução de Gilmar Mendes Ferreira. Porto Alegre: Sergio Antonio Fabris Editor, 1991.

KELSEN, Hans. Teoria Pura do Direito: versão condensada pelo próprio autor. Trad. J. Cretella Jr. E Agnes Cretella. São Paulo: Ed. Revista dos Tribunais, 2011;

LASSALE, Ferdinand. A essência da Constituição. 6. ed. Rio de Janeiro: Lumen Juris, 2001. MACÊDO, Lucas Buril de; PEIXOTO, Ravi Medeiros. Ônus da prova e sua dinamização. $1^{\text {a }}$ ed. Juspodium, 2014. 
MACEDO, Elaine Harzheim. Cidadania e dignidade humana na dimensão do processo: Humanização do processo. Revista de Direito Brasileira|São Paulo, SP. V. 16, n. 7, 2016; p. 256 - 275. jan./abr. 2017. Disponível em: www.indexlaw.org/index.php/rdb/article/download/3102/2818. Acesso: em 15 mai. 2018. MARINONI, Luiz Guilherme; ARENHART, Sérgio Cruz. Curso de Processo Civil: Processo de Conhecimento. V. 2. 11 ed. rev. e atual. - Revista dos Tribunais, 2013.

MITIDIERO, Daniel. Processo justo, colaboração e ônus da prova. Revista do Tribunal Superior do Trabalho, 2012. Disponível em: http://aplicacao.tst.jus.br/dspace/handle/1939/2962. Acesso em: 05 de mai de 2017.

NEVES, Daniel Amorim Assumpção. Manual de Direito Processual Civil. 3. ed. Rio de Janeiro: Forense: São Paulo: Método, 2011.

NERY JR., Nelson; NERY, Rosa Maria de Andrade. Código de processo civil comentando. 16. ed. rev., atual. e amp.. São Paulo: Revista dos Tribunais, 2016.

PAROSKI, Mauro Vasni. Direitos fundamentais e acesso à Justiça na Constituição. São Paulo, LTr, 2008.

SGARBOSSA, Luís Fernando. A Norma Fundamental da Teoria Pura do Direito à Teoria Geral das Normas. Direitos Fundamentais e Justiça - Ano 8, nº 26, p.111-135, jan./mar. 2014. Disponível em: http://dfj.emnuvens.com.br/dfj/article/view/229/743. Acesso em: mai. 2020.

THEODORO JÚNIOR, Humberto. Curso de Direito Processual Civil: Teoria geral do direito processual civil e processo de conhecimento. 53. ed. Rio de Janeiro: Forense, 2012.

VERGARA, Sylvia Constant. Projetos e relatórios de pesquisa em administração. $2^{a}$ ed. São Paulo: Atlas, 1998.

VICENTINI, Fernando Luiz, Teoria da distribuição dinâmica do ônus da prova. Jus Navigandi, Teresina, ano 18, n. 3633, 12 jun.2013. Disponível em: http://jus.com.br/artigos/24683. Acesso em: 22 abr. 2017.

WAMBIER, Luiz Rodrigues; TALAMINI, Eduardo. Curso Avançado de Processo Civil: Teoria Geral do Processo e Processo de Conhecimento. 13. ed. Revista dos Tribunais, 2013.

WATANABE, Kazuo. Acesso à justiça e sociedade moderna. In: GRINOVER, Ada Pellegrini Grinover et al. (Coords.). Participação e processo. São Paulo: Revista dos Tribunais, 1988, p.128. 